\title{
Making the Most of Publishing Software
}

\author{
Terry J. Mahoney \\ Instituto de Astrofísica de Canarias, E-38205 La Laguna, Tenerife, \\ Spain.e-mail: tjm@ll.iac.es
}

\begin{abstract}
Astronomers nowadays have a wealth of sophisticated publishing software at their fingertips, but are they achieving acceptable standards of presentation?
\end{abstract}

\section{Introduction}

Increased commercial pressure on academic publishers to reduce overheads (see Mitton 1992; Sharpe \& Gunther 1994) and the ever-increasing numbers of papers being published each year (Abt 1998) have resulted in more responsibility for quality of presentation being placed on the shoulders of authors and editors of proceedings.

The new technology enables publishers to provide sophisticated macros that obviate the need for traditional typesetting (Heck 1997); authors are now frequently handling this expensive aspect of production. The respective benefits to publishers and authors are much reduced overheads and increased authorial control over the appearance of the final product.

The downside is a general unawareness of good typesetting practice among authors, who receive little or no training in the principles of publishing practice. So much is evident from even a cursory examination of many volumes of conference proceedings, where cost usually forbids much direct publisher intervention in presentation beyond the provision of standardized macros. For more formal products (monographs, textbooks, etc.), publishers are often obliged to redo much of what the author or volume editor has done badly, and this can be extremely expensive (Mitton 1992) since it requires the services of a professional typesetter.

\section{Publishing Practices}

Astronomers need to:

- Read publishers' instructions

- Have at least a survival grasp of LATEX

- Know basic typesetting and page makeup

- Learn to copy-edit 
- Understand what happens between sending an article or proceedings MS to a publisher and its final publication

- Be aware of the problems of presentation

\section{Universality of $\mathrm{IAT}_{\mathrm{E}} \mathrm{X}$ in Astronomy}

Most research journals and science publishing houses now provide $\mathrm{IAT}_{\mathrm{E}} \mathrm{X}$ (Lamport 1986; Goossens, Mittelbach \& Samarin 1994) or TEX (Knuth 1986) macros for authors and volume editors. New researchers should acquire a sound knowledge of $\mathrm{LAT}_{\mathrm{E}} \mathrm{X}$.

\section{Improving Standards}

Apart from writing research articles and contributions to proceedings, a researcher may also occasionally have to edit an entire volume of proceedings. Today's researcher, therefore, needs a basic understanding of typesetting; an editor must also have some idea of page makeup (the arrangement of text and illustration on the page). This knowledge is usually picked up haphazardly. Formal training, both at undergraduate and postgraduate level and including relevant aspects of authorship, editorship and publishing, should be provided by research centres.

\section{Common Errors Committed by Authors}

- Failure to read publishers' instructions

- Redesigning the page layout by altering fount sizes, indentations, line and paragraph spacings, etc. (often done to squeeze too much content within the set page limit)

- Wrong use of founts

- Poor mathematical typesetting

- Ignoring guidelines for tables

- Unawareness of conventions on referencing and bibliographical lists

\section{Common Errors Committed by Editors of Proceedings}

- Failure to read publishers' instructions

- Poor or non-existent copy-editing

- Careless placement of tables and figures

- Failure to provide indices

- Failure to impose series style of presentation on the contributions 
- Non-checking of cross-references within the volume

- Failure to update reference lists before closing the edition

- Failure to meet delivery deadlines

Many of these errors could be avoided through suitable training. A short course in publishing practices might include:

- A description of the publishing process

- The basics of copy-editing

- The elements of typography, correct use of founts, etc.

- Mathematical typesetting

- Typesetting of tables

- Preparation and labelling of illustrations

- Bibliographical referencing

- Page makeup

- Introduction to $\mathrm{IAT}_{\mathrm{E}} \mathrm{X}$ for publishing

- The rudiments of book production

\section{Understanding the Publishing Process}

Publishers and journals can help improve the input for authors and volume editors by:

- Providing explicit and complete instructions to authors and editors

- Explaining to authors and editors exactly what happens to a MS once it is delivered

Many journals and publishing houses do a good job in providing author/editor instructions, but there is generally insufficient information on the publishing process itself (Nature has shown what can be achieved in this respect (e.g., Nature 1999).

Many universities and research centres offer courses in writing and the techniques of communication. Other courses dedicated to publishing skills could be added to these in order to provide a fully rounded training in the presentation of scientific results. 


\section{How Can the IAU Help?}

The problems of quality of presentation could usefully be addressed by Commissions 5 (Documentation and Astronomical Data) and 46 (Teaching of Astronomy).

The shift in the editorial responsibilities of authors could well justify the setting up of an entirely separate commission or WG.

Moves to standardize certain aspects of presentation (referencing styles, etc.) need to be accelerated. The IAU has a crucial role to play here.

Now is a good time to produce an updated Astronomer's Handbook (Pecker 1966; Wilkins 1989). This could be made relevant to all astronomy writers (not just to authors of IAU publications) and could recommend, in agreement with the main peer-review journals, the standardization of referencing styles, physical units, mathematical typesetting, etc. While the nomenclature of astronomical objects, planetary features, etc., is now well in hand through the various nomenclature committees of the IAU, astronomical terminology - which deals with the meanings of the terms used in all branches of astronomy and its related sciences - is by its nature (as part of the living English language) uncontrollable from "above" and is better studied than legislated (Mahoney 1998).

\section{An Editorial Survival Kit}

All astronomy writers should have easy access to the following publications:

\section{Dictionaries:}

- The Concise Oxford Dictionary, 10th edn. (Pearsall 1999; for British English, but now with American spellings included; a very close approximation to the house styles of the main British scientific publishers)

- Webster's Third New International Dictionary (Merriam-Webster 1976; for American English)

- All non-anglophones should have the most up to date version of a relevant bilingual dictionary

Style Guides:

- The Chicago Manual of Style, 14th edn. (University of Chicago 1993) the last word in all aspects of book production)

- Hart's Rules for Compositors and Readers, 39th edn. (Oxford University Press 1983; a compact and highly informative guide to OUP house stylesoon to be updated)

- The Oxford Dictionary for Writers and Editors, 2nd edn. (Ritter 2000; an excellent trouble-shooter; both British and American spellings)

Editorial Manuals:

- Copy-Editing, 3rd edn. (Butcher 1992; an authoritative guide to British editorial practices) 
- Editing Fact and Fiction (Sharpe \& Gunther 1994; a general guide to book editing the American way) The Chicago Manual of Style also gives and exhaustive treatment of American editorial practices.

English Grammar, Punctuation, Style, etc.:

- The Elements of Style, 4th edn. (Strunk \& White 2000; a masterpiece of conciseness-for American English)

- The Right Word at the Right Time (Reader's Digest Association 1985; a superb usage guide for British English with encyclopaedic coverage of the many kinds of English)

If funds will permit another extremely useful guide to academic publishing in all its aspects is the Handbook for Academic Authors (Luey 1997).

\section{Conclusions}

1. Pressure on publishers to reduce overheads and the continuing increase in the number of publications, combined with availability of typesetting software, have shifted a considerable degree of editorial responsibility on to research authors.

2. Astronomical centres should train their research staff in writing and editorial techniques.

3. Astronomers can help themselves by studying the available literature.

4. The IAU could usefully examine the question of the presentational quality of publications.

\section{References}

Abt, H. A. 1998, PASP, 110, 210.

Butcher, J. 1992, Copy-editing, 3rd edn. (Cambridge: Cambridge University Press).

Goossens, M., Mittelbach, F. \& Samarin, A. 1994, The IATEX Companion (Reading, Mass.: Addison-Wesley).

Heck, A. (ed.) 1997, Electronic Publishing for Physics and Astronomy (ApSS, $247,1)$.

Knuth, D. E. 1986, The TEX Book (Reading, Mass.: Addison-Wesley).

Lamport, L. 1986, IATEX: a Document Preparation System (Reading, Mass.: Addison-Wesley).

Luey, B. 1997, Handbook for Academic Authors, 3rd edn. (Cambridge: Cambridge University Press).

Mahoney, T. J. 1998, in ASP Conf. Ser., Vol. 153, Library and Information Services in Astronomy III (LISA III), ed. U. Grothkopf, H. Andernach, S. Stevens-Rayburn, \& M. Gomez (San Francisco: ASP), p. 218. 
Merriam-Webster 1976, Webster's Third New International Dictionary (Springfield, Mass.: Merriam-Webster).

Mitton, S. 1992, in Desktop Publishing in Astronomy and Space Sciences, ed. A. Heck (Singapore: World Scientific), p. 67.

Nature 1999, Cómo se publica en nature: una guía, Nature, 402 (suppl.).

Oxford University Press 1983, Hart's Rules for Compositors and Readers, 39th edn. (Oxford: Oxford University Press).

Pearsall, J. (ed.) 1999, Concise Oxford Dictionary, 10th edn. (Oxford: Oxford University Press).

Pecker, J.-C. 1966, Trans. IAU, XIIC, Astronomer's Handbook (London: Academic Press).

Reader's Digest Association 1985, The Right Word at the Right Time (London: Reader's Digest Association).

Ritter, R. M. (ed.) 2000, The Oxford Dictionary for Writers and Editors, 2nd edn. (Oxford: Oxford University Press).

Sharpe, L. T. \& Gunther, I. 1994, Editing Fact and Fiction (Cambridge: Cambridge University Press).

Strunk Jr., W. \& White, E. B. 2000, The Elements of Style, 4th edn. (Boston: Allyn \& Bacon).

University of Chicago Press 1993, The Chicago Manual of Style, 14th edn. (Chicago: University of Chicago Press).

Wilkins, G. A. 1989, IAU Style Manual (Dordrecht: Kluwer). 